\title{
Implementasi Filter Finite Impulse Response (FIR) Window Hamming dan Blackman menggunakan DSK TMS320C6713
}

\section{LITA LIDYAWATI'1 ${ }^{\text {, PAULINE RAHMIATI }}{ }^{2}$,YULI SUNARTI ${ }^{3}$}

\author{
1,2,3Teknik Elektro Institut Teknologi Nasional (ITENAS) Bandung \\ Email : litalidyawati3@gmail.com
}

\begin{abstract}
ABSTRAK
Filter didefinisikan sebagai proses atau rangkaian yang melewatkan pita frekuensi tertentu yang diinginkan dan meredam pita frekuensi lainnya. Salah satu metode perancangan filter digital Finite Impulse Response (FIR) adalah metode windowing. Dalam penelitian ini digunakan jenis window Hamming dan Blackman. Simulasi dilakukan dengan menggunakan software Matlab dengan memasukan frekuensi passband, frekuensi stopband, ripple passband, dan stopband attenuation. Dengan frekuensi sampling sebesar $15000 \mathrm{~Hz}$, frekuensi passband sebesar $3000 \mathrm{~Hz}$, frekuensi stopband sebesar $5000 \mathrm{~Hz}$. Setelah simulasi dilakukan implementasi filter dengan parameter yang sama menggunakan DSK TMS 320 C6713 dengan bantuan software CCS. Simulasi dan implementasi dilakukan pada semua band frekuensi. Hasil pengujian terhadap implementasi filter adalah respon magnitude, frekuensi cut-off, bandwidth, dan faktor kualitas dengan hasil simulasi tidak menunjukkan perbedaan yang signifikan.
\end{abstract}

Kata kunci: filter digital, windowing, Hamming, Blackman, frekuensi cut-off .

\begin{abstract}
Filter is defined as a process or series that skip certain desired frequency band and other frequency bands drown. One method of designing a digital filter Finite Impulse Response (FIR) is a windowing method. This study used the type of window Hamming and Blackman. Simulations performed using Matlab software by inserting a frequency passband, stopband frequency, passband ripple, and stopband attenuation. With a sampling frequency of $15,000 \mathrm{~Hz}$, a frequency of $3000 \mathrm{~Hz}$ passband, stopband frequency of $5000 \mathrm{~Hz}$. After the simulation is completed, implementation of the filter with the same parameters using TMS $320 C 6713$ DSK with the help of software CCS. Simulation and implmentasi performed on all frequency bands. The test results of the implementation of the filter is the Magnitude response, the cut-off frequency, bandwidth, and quality factor with simulation results showed no significant difference.
\end{abstract}

Keywords: digital filter, windowing, Hamming, Blackman, cut-off frequency. 


\section{PENDAHULUAN}

Filter dapat diartikan sebagai rangkaian yang melewatkan suatu pita frekuensi tertentu yang diinginkan dan meredam pita frekuensi lainnya. Filter dibagi menjadi dua jenis yaitu filter analog dan filter digital. Menurut respon impulse nya filter digital dibagi menjadi dua, yaitu filter Infinite Impulse Filter (IIR) dan filter Finite Impulse Filter (FIR). Filter IIR memiliki keuntungan yaitu membutuhkan koefesien yang lebih sedikit untuk respon frekuensi yang curam sehingga dapat mengurangi jumlah waktu komputasi, tetapi filter IIR sendiri memiliki kelemahan yaitu karena impulse nya yang tidak terbatas sehingga menyebabkan polenya tidak stabil. Berbeda dengan filter yang diinginkan, yaitu Filter FIR memiliki tanggapan impuls yang panjangnya terbatas dan tidak memiliki pole sehingga kestabilannya dapat dijamin. Salah satu metode dalam merancang filter FIR adalah metode windowing. Unjuk kerja metode windowing sangat tergantung tipe window itu sendiri.

Kegiatan penelitian ini mengacu pada beberapa hasil penelitian tentang simulasi, perancangan, dan implementasi filter Finite Impulse Response (FIR) menggunakan MatLab dan DSK (DSP Starter Kit) TMS320C6713, terdapat beberapa penelitian sebelumnya yang menjadi referensi dalam penelitian ini yaitu, pada jurnal penelitian di Electronics and Communication, MIET (KUK) India. yang berjudul "Performance Analysis of FIR Filter Design by Using Rectangular, Hanning and Hamming Windows Methods" menganalisis simulasi filter dengan window rectangular, Hamming dan Hanning pada low pass filter dengan menggunakan software MatLab yang hasilnya berupa perbandingan kinerja masing-masing dari window. (Sonika, 2012).

Pada jurnal penelitian di Universitas Tanjungpura yang berjudul Desain dan Simulasi Filter FIR Menggunakan Metode Windowing yaitu menganalisis filter digital FIR dengan beberapa metode window seperti Rectangular, Hanning , Hamming, dan Blackman pada low pass filter dengan menggunakan software MatLab membandingkan kinerja frekuensi cut-off, transition band, dan pengujian redaman dengan panjang filter yang berbeda-beda. Hasilnya filter FIR sudah dapat memenuhi spesifikasi perancangan filter dengan melewatkan frekuensi yang diinginkan dan meredam frekuensi lainnya. (Mooniarsih, 2010).

Pada jurnal penelitian di Khulna University of Engineering \& Technology, Bangladesh yang berjudul "Comparative Performance Analysis of Hamming, Hanning and Blackman Window" membandingkan kemampuan low pass filter, high pass filter, band pass filter, band stop filter dan all pass filter dari masing masing window yang tediri dari respon Magnitude, respon fasa, bandwidth noise ekivalen, transisi lebar side lobe, respon frekuensi, dan respon dalam waktu mengguakan simulasi MatLab, kemudian dibandingkan dengan teori yang sudah ada. Hasil dari simulasi Matlab dengan teori tidak jauh berbeda. (Prajoy, 2014).

Pada jurnal penelitian di Jurusan Teknik Elektro Fakultas Teknik Universitas Sriwijaya yang berjudul "Perancangan dan Simulasi Low Pass Finite Impulse Response dengan Metode Windowing" menentukan jenis window yang dipakai untuk mendapat redaman sebesar -24 $\mathrm{dB}$ dengan nilai $\mathrm{k}$ terkecil adalah window Bartlet dengan respon frekuensi filter LPF pada frekuensi cut-off, Magnitude impuls respon sebesar $6 \mathrm{~dB}$ dan pada frekuensi stopband redamannya sebesar $35 \mathrm{~dB}$. (Irmawan, 2014).

Pada jurnal penelitian di Institut Teknologi Sepuluh Nopember yang berjudul "Implementasi Filter FIR secara Real Time pada TMS 32C5402" mengimplementasi filter FIR dengan bantuan kit TMS 320C5402 hasil yang diperoleh dari sistem ini menunjukan karakteristik respon frekuensi yang mendekati dengan rumusan yang ada pada teori. (Santoso, 2010) 
Pada jurnal penelitian di Institut Teknologi Nasional Bandung yang berjudul "Implementasi Filter Infinte Impulse Response (IIR) dengan Respon Butterworth dan Chebyshev Menggunakan DSK TMS320C6713" dilakukan simulasi dan implementasi filter IIR dengan menghasilkan respon frekuensi yang dihasilkan tidak jauh berbeda antara simulasi dan implementasi. (Tamba, 2015)

Berdasarkan hasil penelitian diatas maka dilakukan simulasi, perancangan, dan implementasi filter FIR dengan metode window Hamming dan Blackman menggunkan Matlab dan DSP starter kit yaitu DSK TMS320C6713. Dan dipilih window Hamming dan Blackman karena kedua window tersebut memiliki unjuk kerja yang paling mendekati dengan teori yang sudah ada jika dilakukan simulasi dan implementasi. Pada penelitian ini dilakukan pada window Hamming dan Blackman pada LPF, HPF, BPF, BSF dengan parameter frekuensi passband sebesar $3000 \mathrm{~Hz}$, frekeusni stopband sebesar $5000 \mathrm{~Hz}$ dan frekuensi sampling sebesar 15000 $\mathrm{Hz}$.

\section{METODOLOGI}

\subsection{Perancangan Filter FIR}

Sebelum melakukan perancangan, maka terlebih dahulu dilakukan perhitungan untuk mengetahui nilau dari spesifikasi. Dalam perancang filter FIR, respon impulse yang tak terhingga akan terpotong menggunakan teknik windowing, yaitu window Hamming dan Blackman digunakan frekuensi passband (Fp) sebesar $3000 \mathrm{~Hz}$, frekuensi stopband (Fs) sebesar $5000 \mathrm{~Hz}$, frekuensi sampling $15000 \mathrm{~Hz}$, ripple passband sebesar $1 \mathrm{~dB}$ dan ripple stopband sebesar $40 \mathrm{~dB}$. Parameter ini akan digunakan untuk filter LPF, HPF, BSF dan BPF window Hamming dan Blackman (Aryanta, 2015). Spesifikasi nilai ini untuk mendapatkan nilai panjang filter.

1. Spesifikasi yang diinginkan

$$
\begin{aligned}
& \omega_{p}=\frac{2 \pi \cdot F_{p}}{F_{\text {sampling }}}=\frac{2 \pi \cdot 3000}{15000}=0,4 \pi \mathrm{rad} \\
& \omega_{s}=\frac{2 \pi \cdot F_{S}}{F_{\text {sampling }}}=\frac{2 \pi \cdot 5000}{15000}=0,67 \pi \mathrm{rad} \\
& f_{c}=\frac{F_{p}+F_{S}}{2}=\frac{3000+5000}{2}=4000 \mathrm{~Hz} \\
& \omega_{c}=\frac{2 \pi \cdot F_{c}}{F_{\text {sampling }}}=\frac{2 \pi \cdot 4000}{15000}=0,53 \pi \mathrm{rad}
\end{aligned}
$$

Window Hamming

$$
\mathrm{N} \geq \frac{8 \pi}{\omega_{p}-\omega_{s}}=\frac{8 \pi}{0.67 \pi-0,4 \pi}=29,629 \text { diambil } N=31
$$

Window Blackman

$$
\mathrm{N} \geq \frac{12 \pi}{\omega_{p}-\omega_{s}}=\frac{12 \pi}{0.67 \pi-0.4 \pi}=44,44 \text { diambil } N=45
$$




$$
\begin{aligned}
& \alpha \text { dapat dicari dengan } \mathrm{n}=\frac{N-1}{2} \\
& \alpha=\frac{31-1}{2}=15 \text { untuk Hamming window } \\
& \alpha=\frac{45-1}{2}=22 \text { untuk Blackman window }
\end{aligned}
$$

2. Persamaan input respons $\mathrm{h}(\mathrm{n})$ untuk LPF dengan Hamming window :

$$
\begin{aligned}
h_{d}(n) & =\frac{\sin (0.53 \pi(\mathrm{n}-15))}{\pi(n-15)} \\
w_{\text {Ham }}(n) & = \begin{cases}0,54-0,46 \cos \left(\frac{2 \pi n}{N-1}\right), 0 \leq n \leq N-1 \\
0,\end{cases}
\end{aligned}
$$

3. Persamaan input respons $\mathrm{h}(\mathrm{n})$ untuk LPF dengan Blackman window :

$$
\begin{gathered}
h_{d}(n)=\frac{\sin (0.53 \pi(\mathrm{n}-22))}{\pi(n-22)} \\
w_{\text {Blackman }}(n)=\left\{\begin{array}{c}
0,42+0,5 \cos \left(\frac{2 \pi n}{N-1}\right)+0,08 \cos \left(\frac{4 \pi n}{N-1}\right), 0 \leq n \leq N-1 \\
0
\end{array},\right. \text { lainnya }
\end{gathered}
$$

Dengan didapatnya nilai panjang filter diatas, maka akan dipakai untuk membuat respon impulse di simulasi dan implementasi. Nilai panjang filter akan berpengaruh kepada faktor roll-off atau faktor kelandaian dari suatu filter.

\subsection{Perancangan Simulasi dengan Matlab}

Simulasi filter FIR dilakukan dengan dua tahap, yaitu simulasi menggunakan $m$-file kemudian dilanjutkan dengan simulasi Simulink. Hasilnya dari simulasi ini berupa respon frekuensi dari filter tersebut. Hal ini dilakukan agar dapat membandingkan dengan lebih teliti perbedaan antara simulasi dengan $m$-file, simulink, dan hasil implementasi.

\subsubsection{Simulasi menggunakan m-file}

Perancangan simulasi filter FIR dengan penulisan $m$-file bertujuan untuk mendapatkan koefisien filter $b$ dan a (koefisien pembilang dan penyebut fungsi alih filter). Dengan memasukan syntax yang telah dirancang, lalu menghasilkan respon frekuensi dari filter. Langkah-langkah pemodelan simulasi menggunakan $m$-file secara singkat ditunjukan oleh diagram alir pada Gambar 1.

\subsubsection{Simulasi menggunakan Simulink}

Setelah program $m$-file yang dibuat selesai, maka selanjutnya dilakukan simulasi dengan menggunakan simulink. Proses pada simulink juga dipakai saat memasukan parameter yang akan didownload ke kit DSK melalui software CCS. Langkah-langkah pemodelan simulasi menggunakan simulink ditunjukan oleh diagram alir pada Gambar 2 


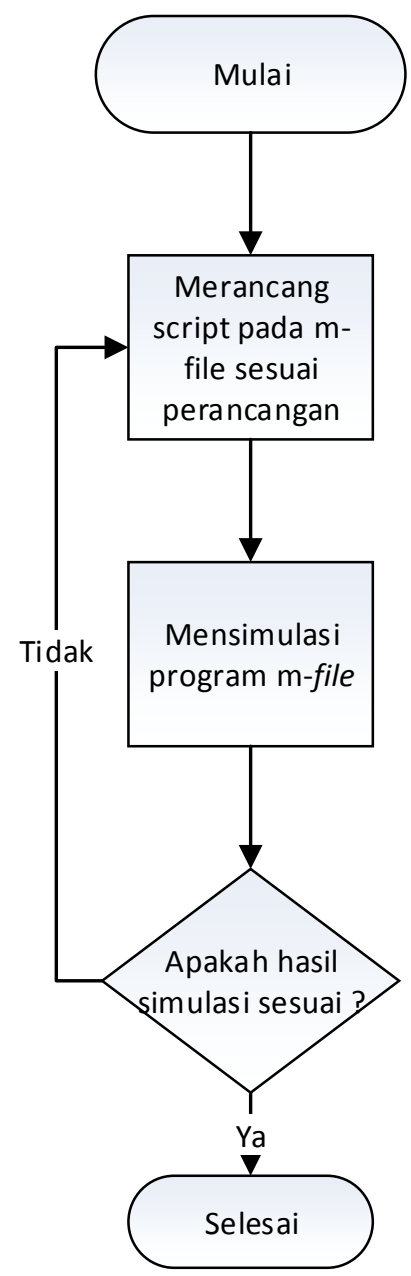

\section{Gambar 1. Diagram Alir tahap simulasi menggunakan m-file}

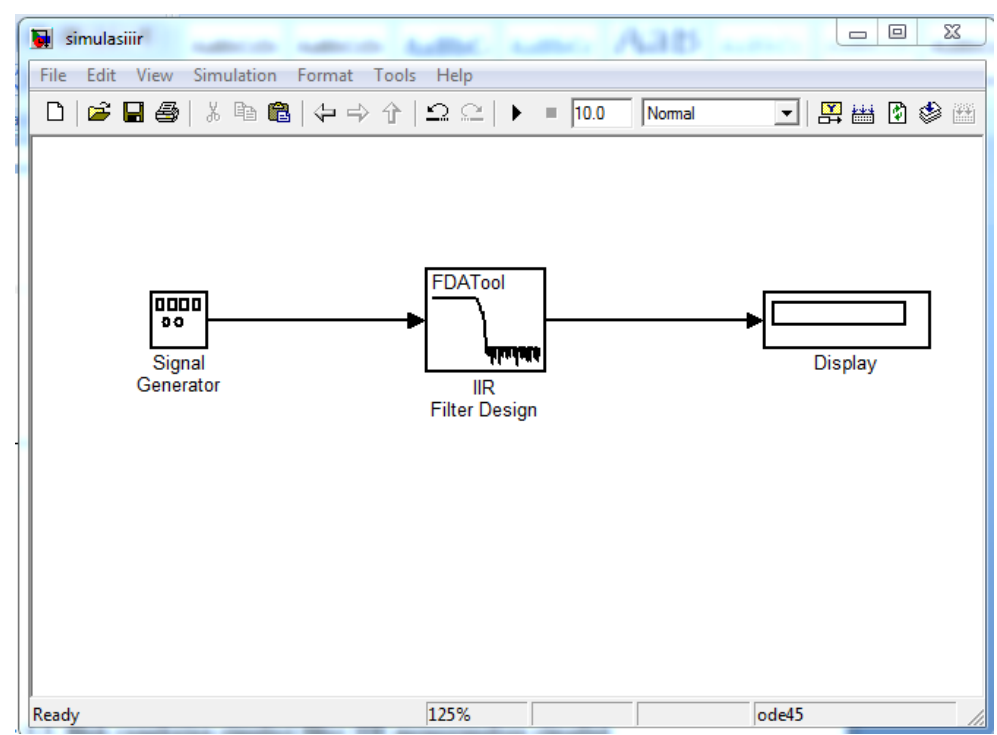

Gambar 2. Blok rangkaian simulasi filter FIR menggunakan simulink 


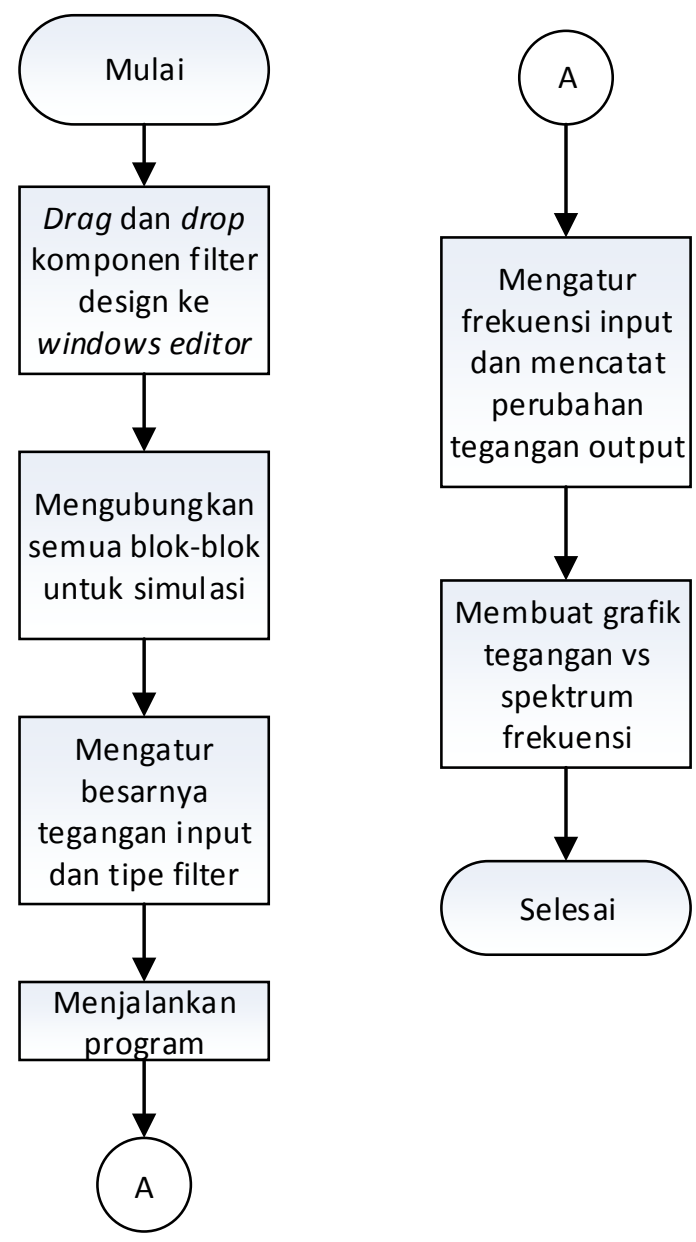

Gambar 3. Diagram alir tahap simulasi menggunakan Simulink

\subsection{Implementasi Filter FIR}

Setelah simulasi selesai dilakukan, maka selanjutnya mengimplementasikan filter yang telah dirancang pada DSK TMS320C6713 dengan bantuan software Code Composer Studio (CCS) untuk menunjukan hasil dari karakteristik filter digital FIR window Hamming dan Blackman pada LPF, HPF, BPF, BSF. Nilai koefisien filter yang diperoleh dari Simulink dengan matlab dicopy ke software CCS yang akan dikompilasi ulang dan hasilnya berupa kode hexa yang akan di-download ke DSK TMS320C6717. Dengan menghubungkan audio generator, DSK TMS 320C6713, PC, dan osiloskop lalu range frekuensi kerja diubah dari audio generator sehingga osiloskop mengeluarkan sinyal yang hasilnya diamati dan dicatat. Hasil tersebut dibuat grafik respon frekeunsi berupa frekuensi terhadap magnitude. Dengan memodelkan sistem kali ini membuat blok diagram dari Simulink matlab dengan blok rangkaian seperti ditunjukan pada Gambar 4. 


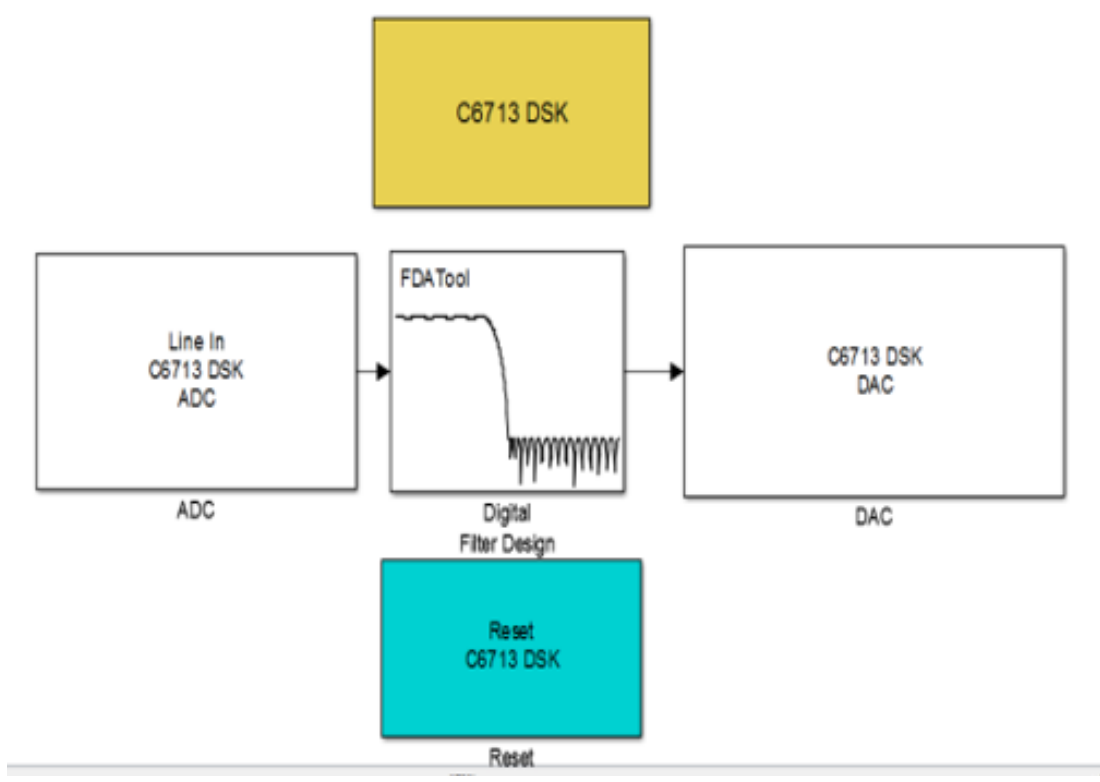

Gambar 4. Blok rangkaian implementasi filter FIR dengan simulink

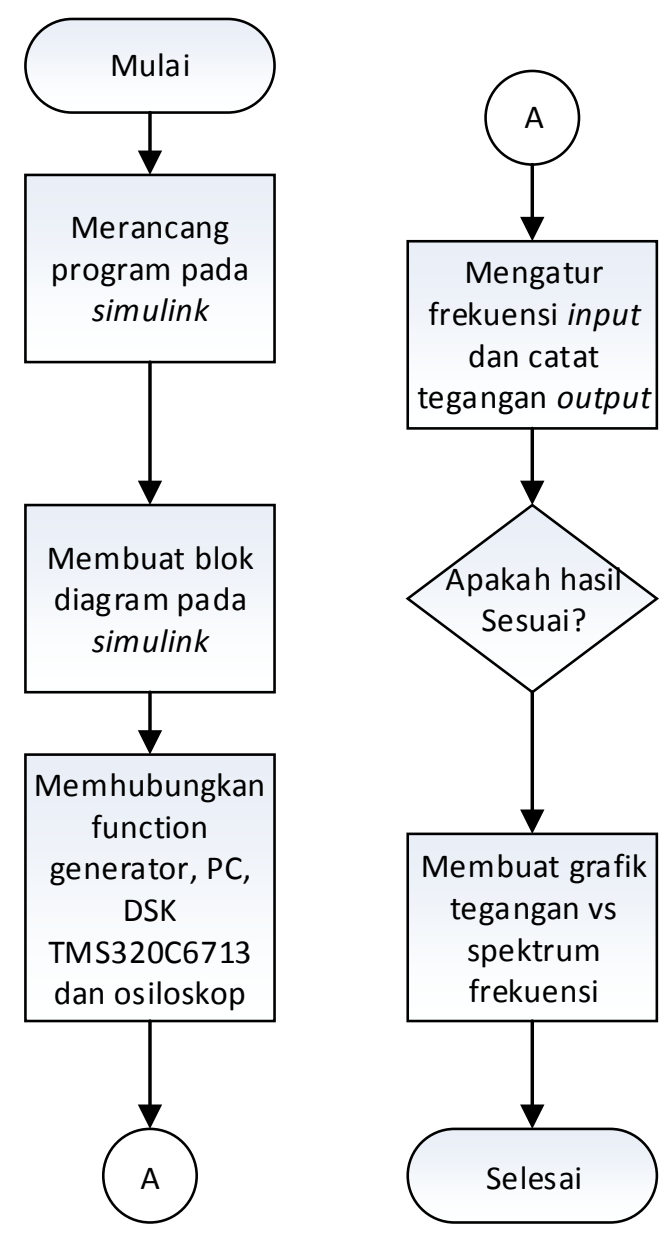

Gambar 5 Diagram Alir Implementasi filter FIR dengan DSK TMS 


\section{PENGUJIAN DAN ANALISIS}

Pada pengujian filter digital FIR dengan metode window Hamming dan Blackman dilakukan simulasi menggunakan Matlab terlebih dahulu, untuk melihat respon frekuensi yang dihasilkan oleh Low Pass Filter (LPF), High Pass Filter (HPF), Band Pass Filter (BPF), dan Band Stop Filter (BSF). Nilai-nilai dari spesifikasi filter yang dimasukan saat simulasi digunakan pada saat implementasi. Pada implementasi dengan DSK TMS3206713 dilihat juga respon frekuensi dari filter-filter seperti di simulasi. Dari pengujian akan didapatkan data yang kemudian dianalisa untuk menentukan unjuk kerja filter hasil rancangan. Hasil dari simulasi dengan Matlab dan implementasi dengan DSK kemudian diuji dan dianalisis dan menghasilkan beberapa hal, seperti :

1. Grafik respon frekuensi Low Pass Filter (LPF), High Pass Filter(HPF), Band Pass Filter (BPF), dan Band Stop Filter (BSF) dari hasil simulasi filter yang menggunakan window Hamming dan Blackman.

2. Grafik respon frekuensi Low Pass Filter (LPF), High Pass Filter (HPF), Band Pass Filter (BPF), dan Band Stop Filter (BSF) dari hasil implementasi filter yang menggunakan window Hamming dan Blackman.

\subsection{Hasil Pengujian dan Analisis dengan Simulasi pada Matlab}

Pengujian dan analisis pada Matlab akan meliputi 4 buah filter yaitu Low Pass Filter (LPF), High Pass Filter (HPF), Band Pass Filter (BPF), Band Stop Filter (BSF) dengan membandingkan respon frekuensi dua metode filter FIR, yaitu window Hamming dan Blackman.

\subsubsection{Simulasi Low Pass Filter (LPF)}

Pada simulasi ini dibuat LPF FIR Hamming dan Blackman yang melewatkan frekuensi dibawah atau frekuensi passband (Fs) sebesar $3000 \mathrm{~Hz}$ dengan ripple passband sebesar (Rp) $1 \mathrm{~dB}$ dan ripple stopband(Rs) sebesar $40 \mathrm{~dB}$ pada saat frekuensi stopband nya $5000 \mathrm{~Hz}$. Data tersebut disampling dengan frekuensi sampling (Fs) sebesar $15000 \mathrm{~Hz}$. Hasil simulasi menghasilkan respon magnitude seperti Gambar 6 sinyal mulai turun dari frekuensi passband (Fs) $3000 \mathrm{~Hz}$. Frekuensi cut-off dilihat dari grafik saat magnitude filter -3dB maka frekuensinya sebesar $3975 \mathrm{~Hz}$. Hasil ini cocok dengan hasil perhitungan yang diperoleh frekuensi cut-off yaitu $3975 \mathrm{~Hz}$. Pada gambar grafik respon frekuensi pada window Hamming memiliki hasil penurunan yang lebih landai sesuai dengan teori karena window Hamming memiliki orde (N) yang lebih kecil dari window Blackman yaitu 31. Semakin kecil nilai orde suatu window, maka akan semakin landai.

\subsubsection{Simulasi High Pass Filter (HPF)}

Pada simulasi ini dibuat HPF FIR Hamming dan Blackman yang melewatkan frekuensi di atas atau frekuensi passband sebesar (Fp) $5000 \mathrm{~Hz}$ dengan redaman passband (Rp) sebesar 1 $\mathrm{dB}$, frekuensi stopband (Fs) $3000 \mathrm{~Hz}$ dan redaman stopband (Rs) $40 \mathrm{~dB}$. Data disampling dengan frekuensi sampling (Fs) sebesar $15000 \mathrm{~Hz}$. Hasil simulasi menghasilkan respon magnitude seperti Gambar 6. Dari grafik simulasi diatas didapatkan respon magnitude HPF dengan window Hamming dan Blackman sinyal mulai naik secara tajam dari frekuensi 3000 $\mathrm{Hz}$ sampai $5000 \mathrm{~Hz}$ dan setelah $5000 \mathrm{~Hz}$ sinyal datar. Dari hasil perhitungan diperoleh frekuensi cut-off sebesar $5000 \mathrm{~Hz}$. Untuk parameter yang sama,orde window Blackman lebih besar dibanding window Hamming, hal ini menyebabkan factor roll-off (tingkat kecuraman) filter dengan window Blackman lebih tajam daripada window Hamming. Orde filter dari window Hamming sebesar 31. Sementara untuk window Blackman sebesar 45. 


\subsubsection{Simulasi Band Pass Filter (BPF)}

Pada simulasi ini dibuat BPF Hamming dan Blackman dengan frekuensi passband $5000 \mathrm{~Hz}-$ $7000 \mathrm{~Hz}$, frekuensi stopband lebarnya $1000 \mathrm{~Hz}$ di kedua sisi passband, redaman passband 1 $\mathrm{dB}$ stopband $80 \mathrm{~dB}$. Data disampling sebesar $15000 \mathrm{~Hz}$. Hasil simulasinya menghasilkan respon magnitude seperti Gambar 6 Sinyal mulai naik dari frekuensi $3000 \mathrm{~Hz}$ sampai 5000 Hz. Dari $5000 \mathrm{~Hz}$ sampai $6000 \mathrm{~Hz}$ sinyal relative datar, lalu dari $6000 \mathrm{~Hz}$ sinyal mulai turun, terlihat ripple pada kedua sisi nya. Dari hasil perhitungan Matlab diperoleh frekuensi cut-off pertama sebesar $4975 \mathrm{~Hz}$ dan frekuensi cut-off kedua sebesar $7000 \mathrm{~Hz}$. Terlihat pada gambar 6 bahwa respon frekuensi window Blackman yang lebih landai. Dengan orde filter pada window Hamming sebesar 31. Sementara orde filter window Blackman sebesar 45. Dengan stopband attenuation gain pada window Hamming sebesar $-52 \mathrm{~dB}$ dan Blackman sebesar $-78 \mathrm{~dB}$

\subsubsection{Simulasi Band Stop Filter (BSF)}

Pada simulasi ini dibuat BSF Hamming dengan frekuensi stopband $5000 \mathrm{~Hz}-7000 \mathrm{~Hz}$, frekuensi stopband lebarnya $1000 \mathrm{~Hz}$ di kedua sisi passband, redaman passband $1 \mathrm{~dB}$ stopband $80 \mathrm{~dB}$. Data disampling sebesar $15000 \mathrm{~Hz}$. Hasil simulasinya menghasilkan respon magnitude seperti Gambar 6 Dari grafik diatas didapatkan respon magnitude BSF dengan window Hamming dan Blackman. Pada window Hamming sinyal mulai turun dari frekuensi $3 \mathrm{kHz}$ sampai $5 \mathrm{kHz}$, dari $5 \mathrm{kHz}-6 \mathrm{kHz}$ sinyalnya diredam sebesar $-50 \mathrm{~dB}$, lalu dari $6 \mathrm{kHz}$ sinyal naik sampai frekuensi $7 \mathrm{kHz}$ dan diatas $7,5 \mathrm{kHz}$ sinyal relative datar. Sama seperti respon magnitude window Hamming, pada window Blackman sinyal mulai turun dari frekuensi $3 \mathrm{kHz}$ sampai $5 \mathrm{kHz}$, dari $5 \mathrm{kHz}-6 \mathrm{kHz}$ sinyalnya diredam sebesar $-70 \mathrm{~dB}$, lalu dari $6 \mathrm{kHz}$ sinyal naik sampai frekuensi $7 \mathrm{kHz}$ dan diatas $7,5 \mathrm{kHz}$ sinyal relative datar. Orde pada window Hamming sebesar 31. Sementara orde filter window Blackman sebesar 45.

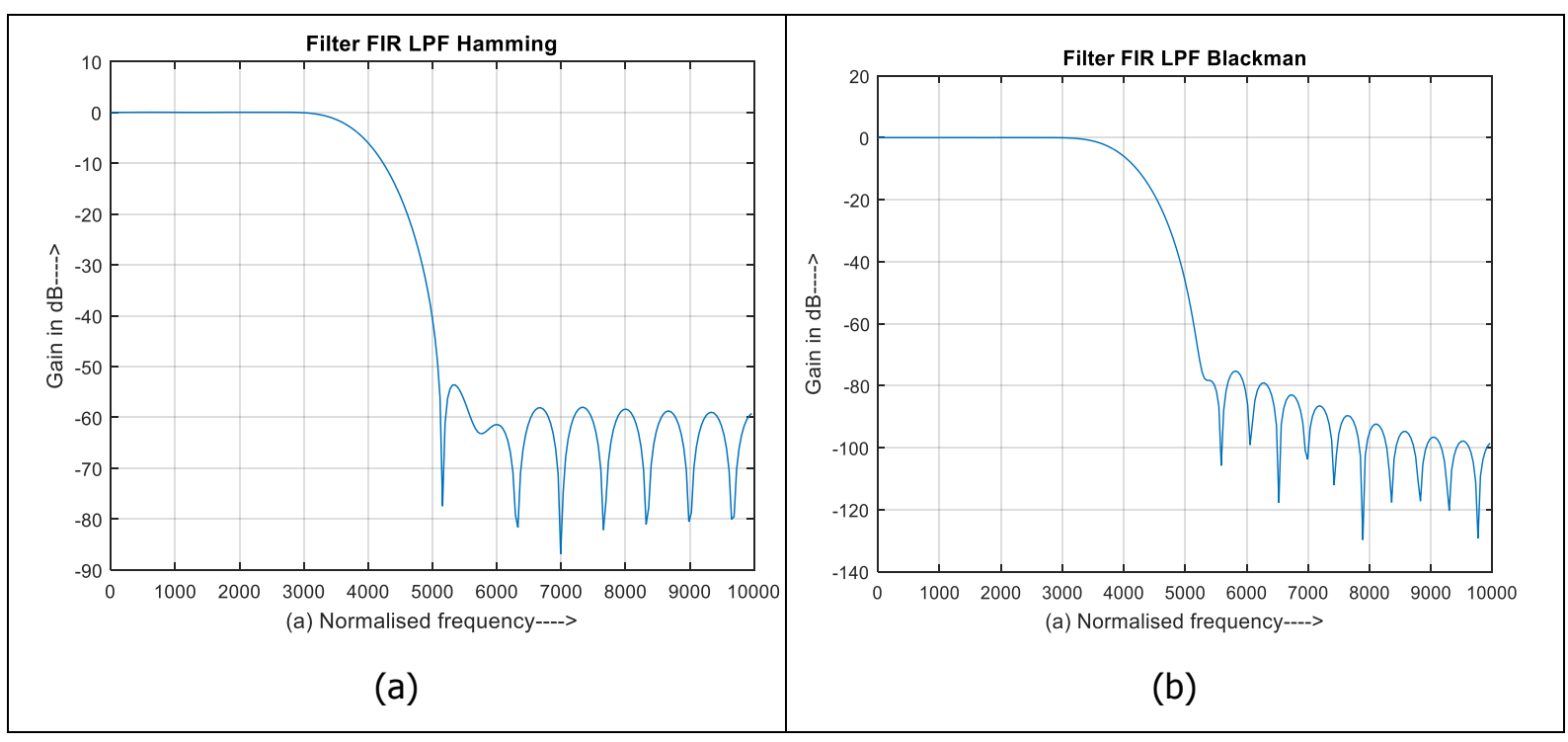

Gambar 6. Respon Magnitude (a) simulasi filter LPF Hamming, (b) simulasi filter LPF Blackman 
Implementasi Filter Finite Impulse Response (FIR) Window Hamming dan Blackman Menggunakan DSK TMS320C6713

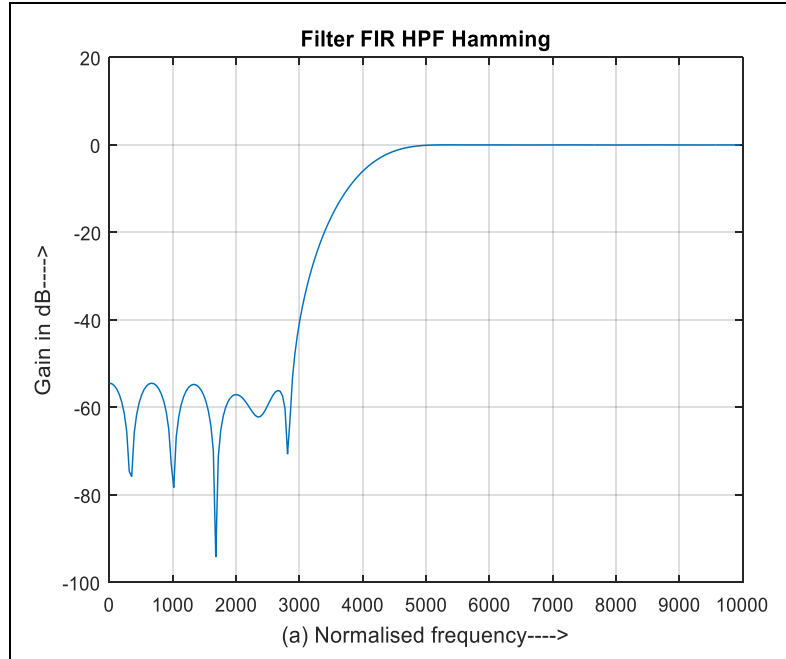

(c)

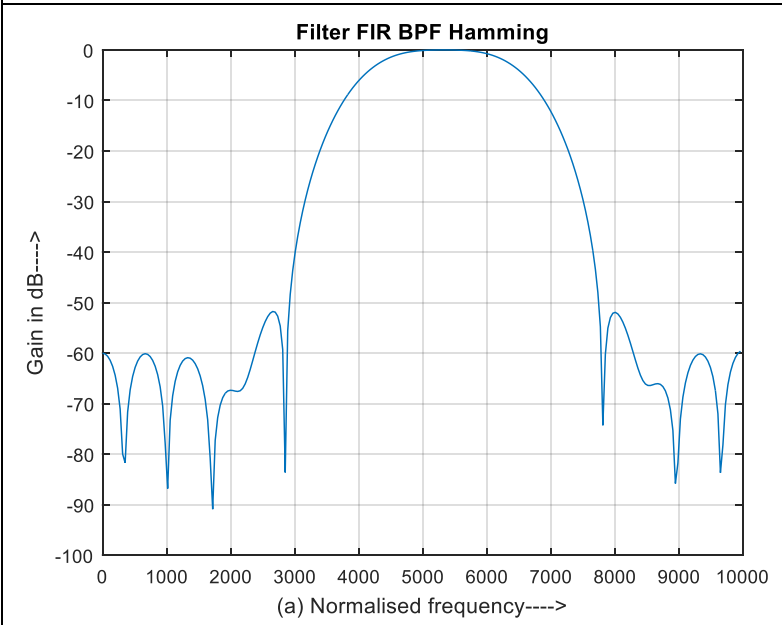

(e)

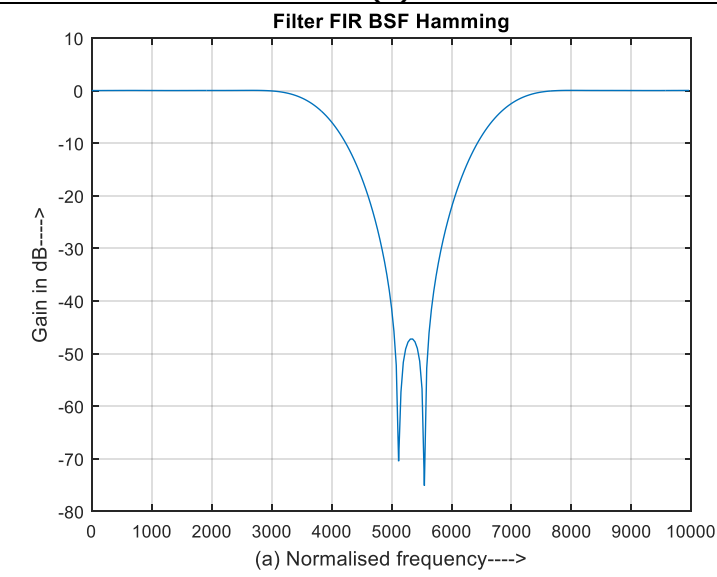

(g)

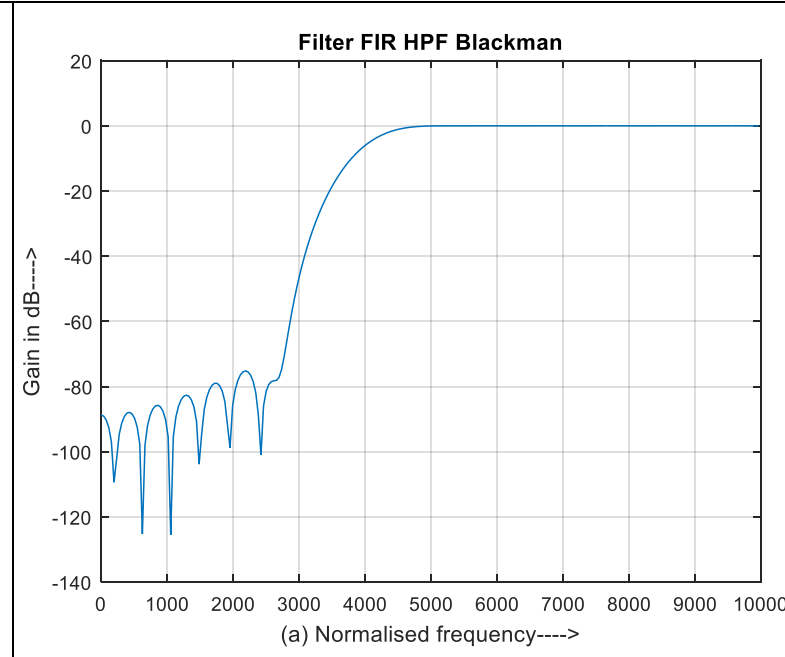

(d)

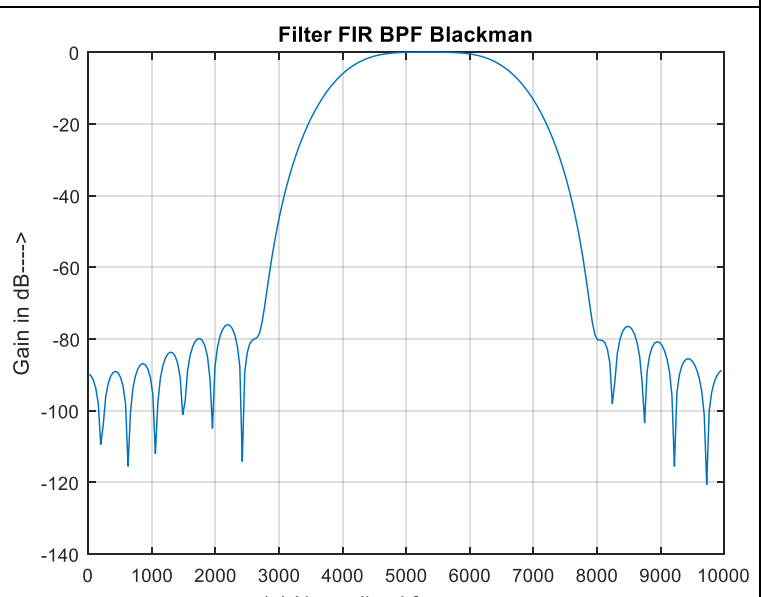

(a) Normalised frequency---->

(f)

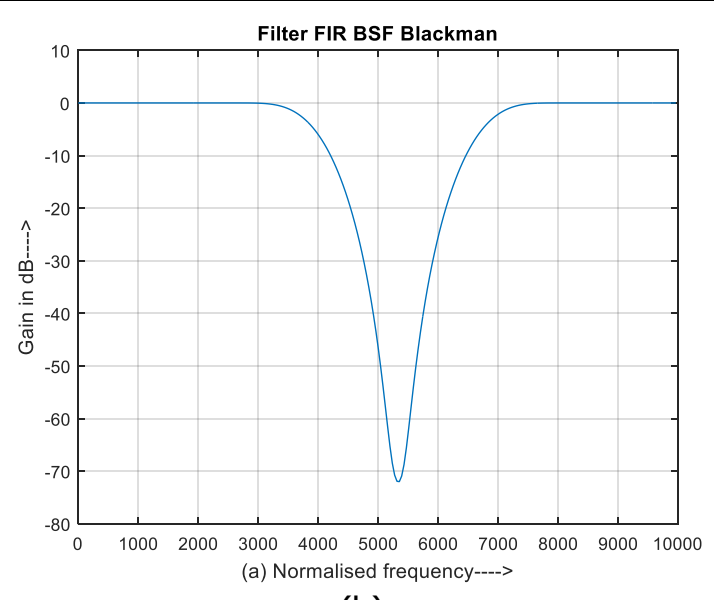

(h)

Gambar 7. Respon Magnitude (c) simulasi filter HPF Hamming, (d) simulasi filter HPF Blackman, (e) simulasi filter BPF Hamming, (f) simulasi filter BPF Blackman, (g) simulasi filter BSF Hamming, (e) simulasi filter BSF Blackman 
Dari semua hasil simulasi diatas, maka hasilnya dapat dirangkum seperti ditunjukan oleh tabel 1 :

Tabel 1. Parameter filter hasil simulasi

\begin{tabular}{|c|c|c|c|c|c|c|c|}
\hline \multirow{2}{*}{ Tipe Filter } & \multirow{2}{*}{$\begin{array}{c}\text { Orde } \\
\text { Filter }\end{array}$} & $\begin{array}{c}\text { Faktor roll- } \\
\text { off } \\
\text { (dB/decade) }\end{array}$ & $\mathbf{F c 1}$ (Hz) & Fc2 (Hz) & $\begin{array}{c}\text { Fttemuation } \\
\text { (dB) }\end{array}$ & BW & $\begin{array}{c}\text { Faktor } \\
\text { kualitas }\end{array}$ \\
\hline LPF Hamming & 31 & -620 & 3975 & - & -52 & - & \\
\hline HPF Hamming & 31 & -620 & 5000 & - & -58 & - & \\
\hline BPF Hamming & 31 & -620 & 4975 & 7000 & -52 & 2025 & 2,95 \\
\hline BSF Hamming & 31 & -620 & 3000 & 7000 & -48 & 4000 & 1,25 \\
\hline LPF Blackman & 45 & -900 & 3975 & - & -78 & - & \\
\hline HPF Blackman & 45 & -900 & 5000 & - & -78 & - & \\
\hline BPF Blackman & 45 & -900 & 4975 & 7000 & -78 & 2025 & 2,95 \\
\hline BSF Blackman & 45 & -900 & 3000 & 7000 & -72 & 4000 & 1,25 \\
\hline
\end{tabular}

\subsection{Hasil Implementasi Filter FIR pada DSK TMS 32066713}

Untuk melihat karakteristik filter Low Pass Filter (LPF), High Pass Filter (HPF), Band Pass Filter (BPF), dan Band Stop Filter (BSF) pada filter FIR metode window Hamming dan Blackman dengan implementasi DSK TMS320C6713, maka digunakan audio generator sebagai pembangkit frekuensi. Kemudian frekuensi diatur sebagai input ke DSK melalui LINE IN, dari LINE OUT di DSK dihubungkan ke osiloskop untuk melihat karakteristik sinyal output (Vout) yang dihasilkan. Hasilnya berupa besarnya tegangan output (Vout) seiring dengan kenaikan frekuensi input. Besarnya tegangan input (Vin) sebesar $6 \mathrm{Vpp}$, frekuensi sampling(Fs) $=15000 \mathrm{~Hz}$, Frekuensi Passband (Fpass) $=3000 \mathrm{~Hz}$, frekuensi stopband (Fstop) $=5000 \mathrm{~Hz}$.

\subsubsection{Implementasi Low Pass Filter (LPF)}

Parameter yang digunakan pada implmenetasi LPF sama seperti perancangan dan simulasi. Besar tegangan input dibuat konstan sebesar $6 \mathrm{Vpp}$. Dari hasil percobaan terjadi drop tegangan dari tegangan input yang terjadi karena adanya rugi-rugi yang berdasal dari kabelkabel yang digunakan untuk menghubungkan hardware yang digunakan maupun hardware (DSK, audio generator, osiloskop, PC). Hasil implementasi dapat dilihat pada Gambar 7. Pada grafik Hamming, sinyal mulai turun pada saat $3000 \mathrm{~Hz}$ sampai $5800 \mathrm{~Hz}$ dan setelah itu terjadi ripple. Untuk mengetahui frekuensi cut-off dari hasil implementasi filter ini, maka dicari dengan mengurangi penguatan passband dengan $-3 \mathrm{~dB}$, yaitu diperoleh sebesar $-7,6$ $\mathrm{dB}-3 \mathrm{~dB}=-10,6 \mathrm{~dB}$. Pada saat Magnitude $-10,6 \mathrm{~dB}$ maka frekuensi cut-off sebesar 3000 $\mathrm{Hz}$. Dengan stopband attenuation yang diperoleh sebesar $-25 \mathrm{~dB}$. Pada grafik Blackman frekuensi cut-off yang diperoleh sebesar $3000 \mathrm{~Hz}$. Sinyal mulai turun saat $3000 \mathrm{~Hz}$ sampai di $5000 \mathrm{~Hz}$ lalu terjadi ripple dan stopband attenuation sebesar $-38 \mathrm{~dB}$.

\subsubsection{Implementasi High Pass Filter (HPF)}

Dari hasil implmentasi dengan menggunkan parameter yang sama dengan simulasi , maka dihasilkan grafik respon Magnitude seperti Gambar 7. Sama seperti LPF untuk mengetahui frekuensi cut-off dicari dengan mengurangi penguatan passband dengan hasil sebesar $-10,6$ $\mathrm{dB}$, maka frekuensi cut-off Hamming sebesar $5600 \mathrm{~Hz}$, sinyal mulai naik pada frekuensi 2800 $\mathrm{Hz}$ sampai di $6800 \mathrm{~Hz}$ setelah itu sinyal mulai datar. Sementara untuk Blackman frekuensi 
cut-off sebesar $4600 \mathrm{~Hz}$, sinyal mulai naik pada $3100 \mathrm{~Hz}$ sampai $4600 \mathrm{~Hz}$ setelah itu sinyal relative datar.

\subsubsection{Implementasi Band Pass Filter(BPF)}

Hasil implementasi dapat dilihat pada gambar 8, pada window Hamming sinyal mulai naik pada $3000 \mathrm{~Hz}$ sampai $5700 \mathrm{~Hz}$ dan sinyal mulai turun pada saat $6000 \mathrm{~Hz}$ sampai $9500 \mathrm{~Hz}$. Besar frekuensi cut-off dan stopband attenuation dapat dilihat di table 2. Dari hasil respon Magnitude BPF Blackman terlihat lebih landai dibanding BPF Hamming.

\subsubsection{Implmentasi Band Stop Filter(BSF)}

Hasil implementasi dilihat pada gambar 8 sinyal mulai turun pada $2500 \mathrm{~Hz}$ sampai $4800 \mathrm{~Hz}$ lalu sinyal mulai naik sampai di $7400 \mathrm{~Hz}$. Pada filter BPF window Hamming hasil implementasi ini terlihat berbeda dengan hasil simulasi. Besar frekuensi cut-off dapat dilihat pada table 2.

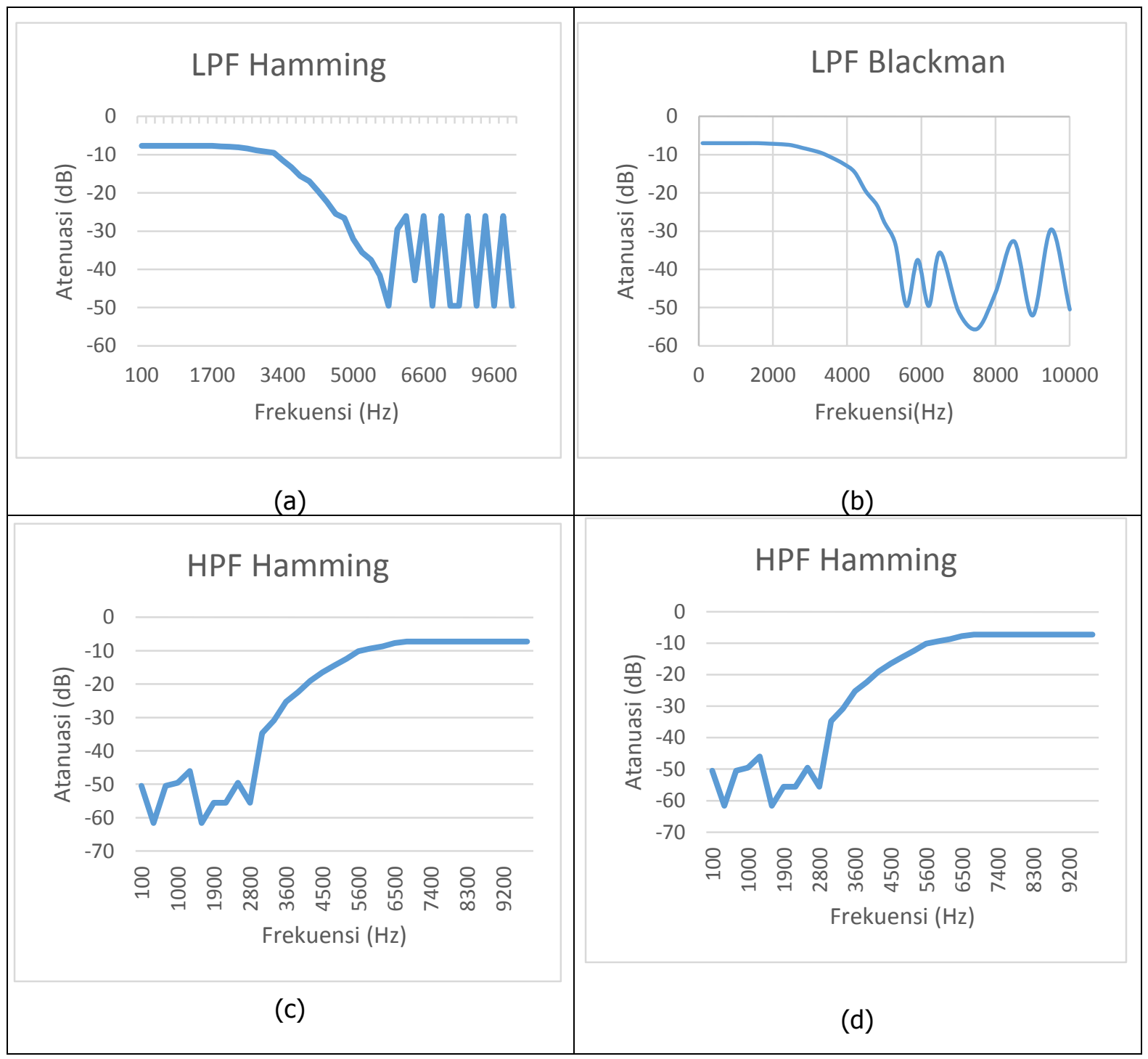

Gambar 8. Respon Magnitude (a) implementasi filter LPF Hamming, (b) implementasi filter LPF Blackman, (c) implementasi filter HPF Hamming, (d) implementasi filter HPF Blackman 


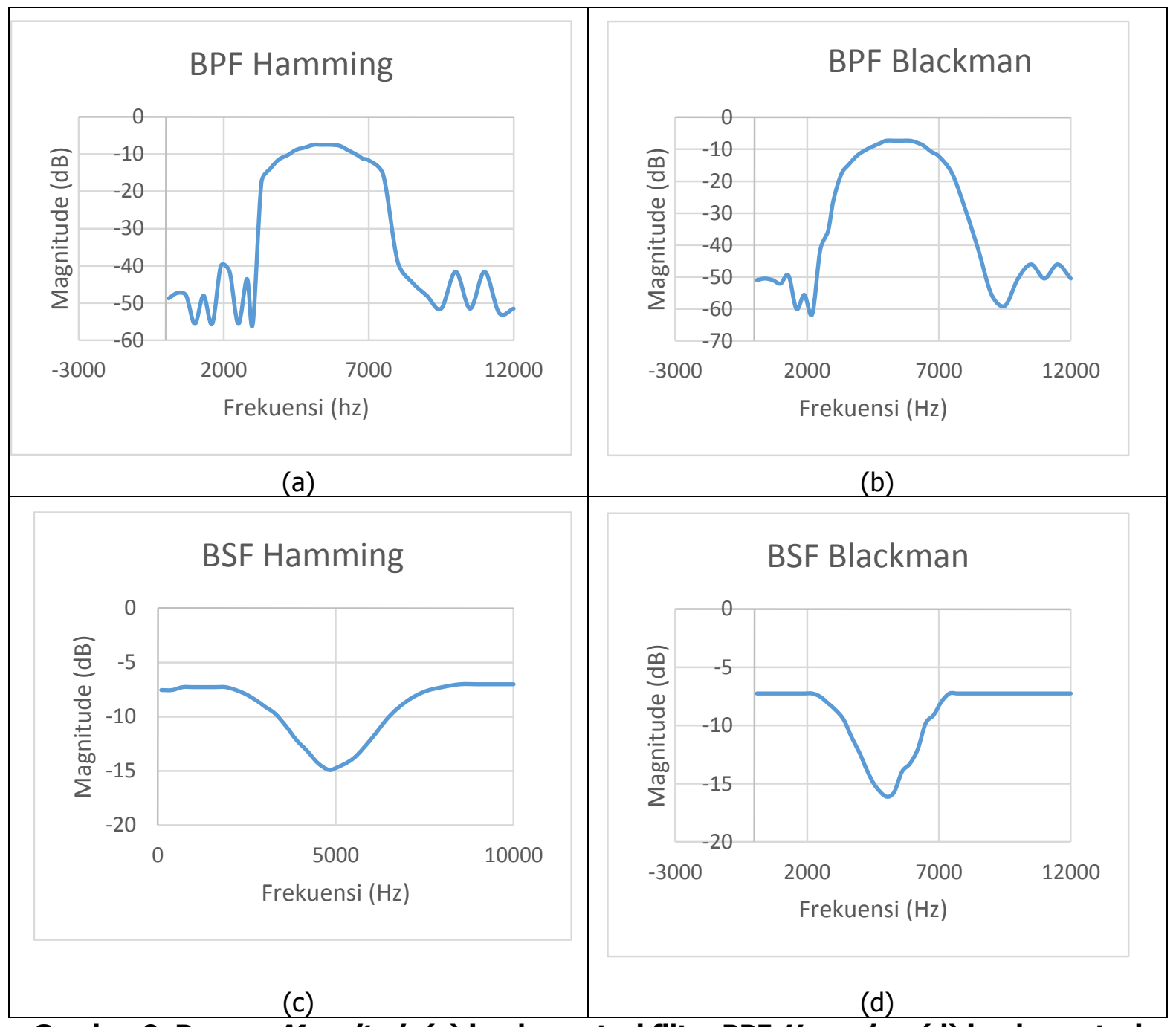

Gambar 9. Respon Magnitude (c) implementasi filter BPF Hamming, (d) implementasi filter BPF Blackman, (e) implementasi filter BSF Hamming, (f) implementasi filter BSF Blackman

Tabel 2. Parameter filter hasil implementasi

\begin{tabular}{|c|c|c|c|c|c|c|}
\hline \multirow{2}{*}{ Tipe Filter } & Orde & \multicolumn{2}{|c|}{ Frekuensi cut-off } & $\begin{array}{c}\text { Stopband } \\
\text { attenuation }\end{array}$ & BW & $\begin{array}{c}\text { Faktor } \\
\text { kualitas }\end{array}$ \\
\cline { 3 - 7 } FPF Hamming & 31 & 3000 & - & -26 & - & \\
\hline HPF Hamming & 31 & 5600 & - & -49 & - & \\
\hline BPF Hamming & 31 & 4200 & 6600 & -41 & 2400 & 2,25 \\
\hline BSF Hamming & 31 & 3600 & 6500 & -14 & 2900 & 1,74 \\
\hline LPF Blackman & 45 & 3600 & - & -37 & - & \\
\hline HPF Blackman & 45 & 4800 & - & -35 & - & \\
\hline BPF Blackman & 45 & 4200 & 6700 & -15 & 2500 & 2,18 \\
\hline BSF Blackman & 45 & 3400 & 6500 & -16 & 3100 & 1,59 \\
\hline
\end{tabular}


Hasil dari simulasi pada tabel 1 , data yang didapat dilihat dari hasil sinyal keluaran dan hasil implementasi pada tabel 2 data yang didapatkan dari hasil gambar sinyal keluaran dari osiloskop dapat dibandingkan parameter filter berupa pengujian frekuensi cut-off yang bertujuan untuk mengetahui ketepatan frekuensi cut-off hasil simulasi dengan hasil implementasi yang hasilnya tidak ada penyimpangan yang cukup signifikan. Pada pengujian redaman stopband attenuation atau nilai gain tertinggi yang terjadi di daerah stopband yang bertujuan untuk mengetahui besarnya redaman yang dihasilkan filter. Secara teoritis semakin kecil atau semakin negative nilai redaman maka filter semakin baik, hal ini dikarenakan frekuensi yang tidak diinginkan dapat benar-benar dilemahkan, pada hasil percobaan simulasi lebih baik dibanding hasil implementasi. Sementara dari factor kualitas untuk filter BPF dan BSF Hamming dan Blackman hasil simulasi dan implementasi tidak terjadi penyimpangan yang jauh.

\section{KESIMPULAN}

\subsection{KESIMPULAN}

Setelah melakukan pengujian dan analisis dari simulasi dan implementasi filter FIR dengan metoda window Hamming dan Blackman, maka diperoleh kesimpulan, yaitu Frekuensi cut-off hasil simulasi pada LPF Hamming dan Blackman sebesar 3975 Hz HPF Hamming dan Blackman sebesar 5000 Hz, BPF Hamming dan Blackman sebesar 4975 Hz dan 7000 Hz, BSF Hamming dan Blackman sebesar $3000 \mathrm{~Hz}$ dan $7000 \mathrm{~Hz}$. Untuk faktor kualitas BPF Hamming dan Blackman sebesar 2,95. Sementara untuk BSF Hamming dan Blackman sebesar 1,25. Frekuensi cut-off pada hasil implementasi pada LPF Hamming $3000 \mathrm{~Hz}$ dan Blackman sebesar 3600 Hz, HPF Hamming $5600 \mathrm{~Hz}$ dan Blackman sebesar $4800 \mathrm{~Hz}$, BPF Hamming $4200 \mathrm{~Hz}$ dan $6600 \mathrm{~Hz}$, Blackman sebesar $4200 \mathrm{~Hz}$ dan $6700 \mathrm{~Hz}$, BSF Hamming $3600 \mathrm{~Hz}$ dan $6500 \mathrm{~Hz}$, Blackman sebesar $3400 \mathrm{~Hz}$ dan $6500 \mathrm{~Hz}$. Untuk faktor kualitas BPF Hamming sebesar 2,25 BPF Blackman sebesar 2,18 dan BSF Hamming sebesar 1,74 BSF Blackman sebesar 1,59.

Dari hasil simulasi dan implementasi tidak terlihat perbedaan yang signifikan. Hasil stopband attenuation simulasi LPF dan HPF Hamming sebesar -52 dB dan Blackman sebesar -78 dB, BPF Hamming -52 dB, Blackman sebesar -78 dB, BSF Hamming -48 dB, Blackman sebesar $72 \mathrm{~dB}$. Hasil stopband attenuation implementasi LPF Hamming sebesar -26 dB dan Blackman sebesar -37 dB, HPF Hamming sebesar -49 dB dan Blackman -35 dB. BPF Hamming $-41 \mathrm{~dB}$, Blackman sebesar $-15 \mathrm{~dB}$, BSF Hamming $-14 \mathrm{~dB}$, Blackman sebesar $-16 \mathrm{~dB}$. Dari hasil diatas stopband attenuation yang baik adalah hasil simulasi karena nilainya semakin kecil atau semakin negative sehingga frekuensi yang tidak diinginkan dapat benar-benar dihilangkan atau dilemahkan hal ini dapat terjadi karena ada drop tegangan yang terjadi karena adanya rugi-rugi (loss) yang berasal dari kabel-kabel yang digunakan saat implementasi. Faktor $\mathrm{Q}$ (Faktor Kualitas) pada hasil simulasi window Hamming dan Blackman mempunyai nilai yang sama, karena nilai frekuensi cut-off yang sama, nilai faktor kualitas berpengaruh pada bandwidth. Semakin besar nilai Q, maka lebar BW semakin besar. Respon Magnitude LPF, HPF dan BPF yang dihasilkan dari implementasi dengan DSK TMS320C6713 tidak berbeda jauh dengan hasil simulasi yang dihasilkan Matlab, tetapi cukup berbeda di-ripple nya, sementara pada BSF respon Magnitude yang dihasilkan cukup berbeda dengan simulasinya.

\subsection{SARAN}

Agar penelitian kedepannya menjadi lebih baik, maka perlunya untuk melakukan pengujian yang lebih banyak lagi dengan beragam sinyal input yang berbeda, misalnya sinyal suara 
dan sinyal audio. Untuk mendapatkan hasil yang lebih baik juga diperlukan untuk melakukan pengujian dengan berbagai jumlah yang bervariasi sehingga diperoleh nilai yang optimal. Diharapkan simulasi dan impementasi filter FIR ini dapat dibuat dengan metode window yang berbeda seperti Rectangular, Kaisar, Hanning sebagai perbandingan terhadap window Hamming dan Blackman dengan software Matlab ataupun software lain dan Digital Signal Processor (DSP) dengan DSK TMS320C6713 atau kit DSP lainnya.

\section{DAFTAR RUJUKAN}

Irmawan. (2012). Perancangan dan Simulasi Low Pass Finite Impulse Response dengan Metode Windowing. Palembang: Universitas Sriwijaya.

Mooniarsih, Neilcy. (2010). Desain dan Simulasi Filter FIR menggunakan Metode Windowing. Pontianak: Universitas Tanjungpura.

Sonika, Gupta. (2012). Performance Analysis of FIR Filter Design by Using Rectangular, Hanning and Hamming Windows Methods. Electronics and Communication. India: MIET(KUK).

Prajoy, Podder. (2014). Comparative Performance Analysis of Hamming, Hanning and Blackman Window. Bangladesh: Khulna University of Engineering \& Technology.

Santoso, Tri Budi. (2010). Implementasi Filter FIR secara Real Time pada TMS 32C5402. Surabaya: Institut Teknologi Sepuluh Nopember.

Tamba, Alfin (2015). Implementasi Filter Infinte Impulse Response (IIR) dengan Respon Butterworth dan Chebyshev menggunakan DSK TMS320C6713. Jurnal Elektro Telekomunikasi Terapan (JETT). 2(2): 93 - 103.

Aryanta, Dwi. (2015). Perancangan dan Implementasi Sistem Orthogonal Frequency Division Multiplexing (OFDM) menggunakan DSK TMS320C6713. Jurnal Elektro Telekomunikasi Terapan (JETT). 2(3) : $126-136$. 